\title{
Market volatility of banking stock return vis-à-vis banks merger: An application of GARCH model
}

\author{
Azeem Ahmad Khan ${ }^{a^{*}}$ and Adil Zia ${ }^{a}$
}

${ }^{a}$ College of Business Administration, Al Baha University, Al Baha, Kingdom of Saudi Arabia

\begin{tabular}{l}
\hline C H R O N I C L E \\
\hline Article history: \\
Received: December 18, 2018 \\
Received in revised format: Feb- \\
ruary 12, 2019 \\
Accepted: February 18, 2019 \\
Available online: \\
February 18, 2019 \\
\hline Keywords: \\
Merger \\
Volatility \\
Stock return \\
SBI \\
Garch
\end{tabular}
A B S T R A C T

The objective of this research was to investigate the effects caused by the announcement of mergers of SBI and its associate banks i.e. State Bank of Bikaner and Jaipur (SBBJ), State Bank of Hyderabad (SBH), State Bank of Mysore (SBM), State Bank of Patiala (SBP) and State Bank of Travancore (SBT) with State Bank of India on the volatility of the return of SBI stock during the event window of 300 days. In order to achieve the proposed objective, this study applied Generalized autoregressive conditional heteroscedasticity (Garch) class model to the return series to model their volatility because it is considered an important tool for time series data analysis. Our results confirmed the impact of the announcement of Merger on volatility. The results suggest that merger announcement was expected to cause a reaction in the returns, which is related to higher abnormal return in lesser time through merger announcement for investors.

(C) 2019 by the authors; licensee Growing Science, Canada

\section{Introduction}

The mergers announcements are always a critical issue regarding decisions for expansion of companies' growth and development. The decision for announcements of M\&As mainly focuses on variability of the returns of securities, systematic risk and least associated with trading volume and returns. There may be a difference between the initial effects of an announcement and their subsequent impacts, markets are quite efficient in the sense that prices adjust very quickly to the public news releases. However, an announcement decreases information asymmetry and uncertainty for future rewards. Due to the volatility effect, the efficiency of the firm's contracting activities lies on underlying uncertainty about future outcomes. The merger and acquisitions were started in the beginning of late $19^{\text {th }}$ century. The first great merger movement was started from 1895-1905. During this period small firms with little market share consolidated with similar firms to form a large firm to dominate the market. In 1900, the merger acquired nearly $20 \%$ of growth domestic product (GDP) of the nation and nearly more than 1,800 of these firms disappeared after the merger. One of the major factors of great merger movement was to keep high price, because high prices attracted the firms to enter into the industry and to maintain profitability. The economic history of the merger and the acquisitions have been divided into the number of merger waves based on the merger activities in the business world shown in Table 1. During the period from 1985 to

* Corresponding author.

E-mail address: aakcommerce@gmail.com (A. A. Khan)

(C) 2019 by the authors; licensee Growing Science, Canada doi: $10.5267 /$ j.msl.2019.2.008 
2018, Merger and Acquisitions (M\&As) occurred around the world in terms of the numbers and the value in the banking sector shown in Table 2 followed by Fig. 1. Previously various studies carried out in this field, here the researchers enlightened some studies which are particularly in the banking sector.

The Fama and Miller (1972) market model and Cox and Portes (1998) two factor model form the theoretical framework of this study. The aim is to understand the shareholder wealth effects of bank mergers. Jayaraman et al. (1991) in their research which is based on empirical findings found that market forecasting or anticipation about merger of the targeted firm plays significant role while the first announcement has not been done for the merger. The market anticipation or projection is analyzed by variances existed in target firms' stocks by listing the call options in Premia. Boon Tan, and Wooi Hooy (2004) examined the merger program initiated in Malaysia and investigated the impact of this whole merger program on stock returns and fluctuations in stocks of the Malaysian banks. According to the study, financial sector of the Malaysia suffered from the uncertainty due to financial crisis occurred worldwide in general and Asia in specific and needed some fundamental reforms in the banking sector of Malaysia. The findings of the study suggested that prosperity in stock prices and return would be the outcome of merger program as it is based on projections of conditional variances. Karmakar (2005) did empirically traced the volatility in Indian stock market and for this author used conditional volatility model. The leverage effect has been checked by the author in Indian companies taking two national level stock market indices as Nifty and Sensex. Alberg et al. (2008) made an attempt to determine the asymmetry in volatility through GARCH and EGARCH model. Anand and Singh (2008) attempted to judge the effect of wealth of shareholder by merger in the banking sector of India. The study was focused on five bank mergers. Khan (2011) shed light on pre and post-merger environment of Indian banking sector by computing some financial ratios such as ROCE, Gross and Net profit margin, etc. The author tried to explore various motives behind the M\&A. The author did extensive study on the work accomplished previously on this aspect and found that plethora of work had been executed on impact on M\&A on many aspects of the companies but performance during pre and post-merger was relatively new area to search. Khan and Ikram (2012) critically examined the efficiency of the Indian Stock Market with respect to the announcement of Mergers and Acquisitions (M\&As) in the Indian Banking Sector by employing the Standard Risk Adjusted Event Study Methodology. They took 6 recent mergers from $21^{\text {st }}$ Jan 2003 to $19^{\text {th }}$ May 2009. The result supported that the efficiency of the market in its semi-strong form of EMH and observed that neither before nor after the merger announcement investors were able to earn abnormal/excess return. Shanmugasundram et al. (2013) highlighted the risk factors in sector-based Index. The study was performed on some reputed indices such as CNX Nifty Index, FMCG, AUTO index, etc. ranging the financial year from 2004 to 2012. With the help of two tailed T-Test and ANOVA, it was observed that significant difference did not exist among the sectoral indices risk and CNX Nifty as the Standard deviation was insignificant. Zhu et al. (2014) empirically investigated the effect of idiosyncratic volatility on various acquisition parameters. The study found positive relationship between the aspects. The authors emphasized that knowing this relationship is necessary especially where the information of poor economies exists because acquirers do not have the information of the target company. Birau et al. (2015) tried to capture the volatility of BANKEX by the famous econometrics modeling tools GARCH. BANKEX is the index used to measure the performance of Indian Banking sector. The period taken for the analysis was from January 2002 to June 2014. The authors concluded that this index increased seventeen times in just twelve years and showed clockwise positive returns. Pessanha et al. (2016) studied the impact of announcement of M\&A on stock volatility of Brazilian Banks during the period 1994-2015. By using the GARCH model, the authors revealed that low reputed Banks were associated with negative reactions while high reputed Bank were attached with positive reactions due to the announcement of M\&A. Khan and Javed (2017) investigated how the National and International market, namely (S\&P BSE Sensex) (Nasdaq) (SSE) (FTSE) could influence the volatility of (S\&P BSE BANKEX) return in India. Seo et al. (2019) created the hybrid model for prediction of volatilities in more accuracy manner. The authors used Google Domestic Trends (GDTs) as a raw material to predict the accurate volatility. 
Table 1

Exhibit the History of Merger Waves and Facet during Period

\begin{tabular}{lll}
\hline Period & Waves & Type/ Facet of Merger \\
\hline $1893-1904$ & First Wave & Horizontal mergers \\
$1919-1929$ & Second Wave & Vertical mergers \\
$1955-1970$ & Third Wave & Diversified conglomerate mergers \\
$1974-1989$ & Fourth Wave & Co-generic mergers; Hostile takeovers; Corporate Raiding \\
$1993-2000$ & Fifth Wave & Cross-border mergers, mega-mergers \\
$2003-2008$ & Sixth Wave & Globalizations-, Shareholder Activism, Private Equity, LBO \\
$2014-$ & Seventh Wave & Generic/balanced, horizontal mergers of Western companies acquiring emerging market resource producers \\
\hline Source $:$ Researchers Compilations &
\end{tabular}

Source: Researchers Compilations

Table 2

Showing the M\&As in Banking Sector in the World in Terms of Value and Numbers.

\begin{tabular}{|c|c|c|c|c|c|}
\hline \multirow[t]{2}{*}{ Year } & \multirow[t]{2}{*}{ Number } & \multicolumn{4}{|c|}{ Value in terms of } \\
\hline & & in bil. USD & in bil. EUR & in bil. GBP & in bil. YEN \\
\hline 1985 & 247 & 13 & 17 & 10 & 3183.1165 \\
\hline 1986 & 386 & 25 & 26 & 17 & 4151.9123 \\
\hline 1987 & 468 & 34 & 29 & 21 & 4868.1546 \\
\hline 1988 & 409 & 25 & 19 & 14 & 3161.2157 \\
\hline 1989 & 634 & 51 & 46 & 32 & 7180.116 \\
\hline 1990 & 979 & 50 & 37 & 27 & 6914.9899 \\
\hline 1991 & 1,024 & 52 & 42 & 31 & 7061.4141 \\
\hline 1992 & 954 & 54 & 42 & 30 & 6907.022 \\
\hline 1993 & 914 & 37 & 32 & 25 & 4104.6942 \\
\hline 1994 & 1,027 & 48 & 40 & 31 & 4816.1183 \\
\hline 1995 & 1,192 & 159 & 124 & 101 & 15103.413 \\
\hline 1996 & 1,036 & 71 & 56 & 45 & 7782.3686 \\
\hline 1997 & 975 & 194 & 172 & 118 & 23942.205 \\
\hline 1998 & 1,025 & 466 & 423 & 281 & 61707.784 \\
\hline 1999 & 1,011 & 494 & 483 & 307 & 55247.477 \\
\hline 2000 & 1,041 & 236 & 257 & 156 & 25473.242 \\
\hline 2001 & 895 & 194 & 219 & 136 & 24012.768 \\
\hline 2002 & 715 & 74 & 77 & 49 & 9175.2299 \\
\hline 2003 & 750 & 144 & 124 & 86 & 16257.401 \\
\hline 2004 & 796 & 250 & 200 & 136 & 26906.964 \\
\hline 2005 & 765 & 249 & 201 & 138 & 27340.994 \\
\hline 2006 & 884 & 286 & 225 & 153 & 33366.257 \\
\hline 2007 & 869 & 459 & 332 & 226 & 54453.298 \\
\hline 2008 & 1,107 & 366 & 262 & 210 & 37067.499 \\
\hline 2009 & 1,295 & 252 & 185 & 164 & 23424.734 \\
\hline 2010 & 1,151 & 144 & 110 & 94 & 12472.306 \\
\hline 2011 & 925 & 96 & 70 & 60 & 7670.7227 \\
\hline 2012 & 898 & 187 & 144 & 117 & 15548.148 \\
\hline 2013 & 883 & 78 & 59 & 50 & 7723.946 \\
\hline 2014 & 913 & 95 & 73 & 58 & 10148.941 \\
\hline 2015 & 905 & 107 & 97 & 70 & 12942.524 \\
\hline 2016 & 899 & 95 & 86 & 70 & 10430.043 \\
\hline 2017 & 802 & 89 & 78 & 68 & $9,951.52$ \\
\hline 2018 (June) & 287 & 39.52 & 32.96 & 28.80 & $4,310.21$ \\
\hline 2018 (Forecast) & 541 & 35.421608 & 28.848444 & 25.527431 & 3871.9492 \\
\hline
\end{tabular}

Source: Institute of Mergers, Acquisitions and Alliances (IMAA) analysis

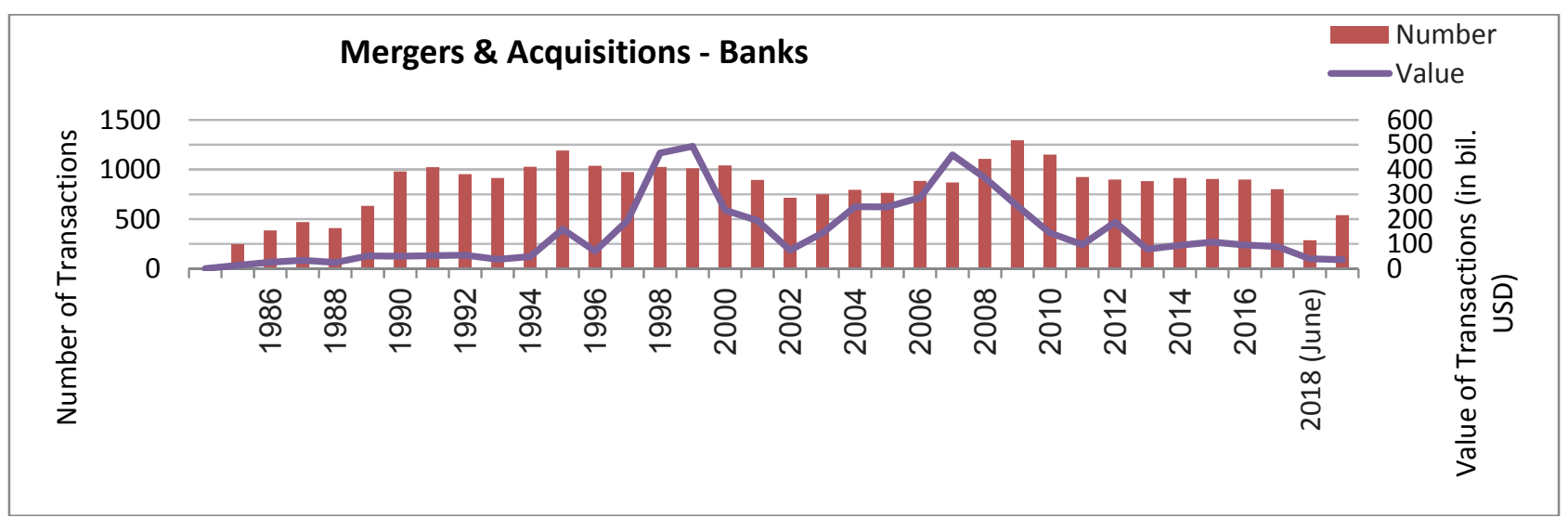

Source: Institute of Mergers, Acquisitions and Alliances (IMAA) analysis (2018)

Fig. 1. Exhibits the Merger and Acquisition(M\&As) in the Banking Sector around the World 


\section{Merger and Acquisitions (M\&As) In Indian Banking Sector}

In the history, the Indian banking sector has witnessed great mergers occurred in the recent decade which includes one of the most prominent mergers that is SBI with their associate banks in 2017. The restructuring through merger, SBI gained a large number of customers within less time and increased the scale of their business. Mergers bring better efficiency ratio in the operations of business which minimize the inherent risk by merging into one. Mergers help in improving the professional standards, where the banks' employees will be under one umbrella to their services and wages by removing disparities. Merger and Acquisitions (M\&As) were started several years ago in the banking sector of India. The oldest and the largest bank still active, i.e., the State Bank of India (S.B.I).

Table 3

Exhibit the List Banks Merger and Acquisitions (M\&As) Since Nationalization of Banks in India

\begin{tabular}{|c|c|c|}
\hline Name of the Banks Acquired & Name of the Banks got Merged & Year of Merging happened \\
\hline State Bank of India & Bharativa Mahila Bank (BMB) & 2017 \\
\hline State Bank of India & State Bank of Travancore (SBT) & 2017 \\
\hline State Bank of India & State Bank of Bikaner and Jaipur (SBBJ) & 2017 \\
\hline State Bank of India & State Bank of Hyderabad (SBH) & 2017 \\
\hline State Bank of India & State Bank of Mysore (SBM) & 2017 \\
\hline State Bank of India & State Bank of Patiala (SBP) & 2017 \\
\hline Kotak Mahindra Bank & ING Vyasa Bank & 2014 \\
\hline ICICI Bank & Bank of Rajasthan Ltd. & 2010 \\
\hline HDFC Bank & Centurion Bank of Punjab & 2008 \\
\hline ICICI Bank Ltd & Sangli Bank & 2007 \\
\hline Indian Overseas Bank & Bharat Overseas Bank & 2007 \\
\hline Centurion Bank of Punjab & Lord Krishna Bank & 2006 \\
\hline Federal Bank & Ganesh Bank of Kurandwad & 2006 \\
\hline Nainital Bank & Bank of Baroda & 2006 \\
\hline IDBI Ltd & United Western Bank & 2006 \\
\hline IDBI Ltd & IDBI Bank & 2005 \\
\hline Bank of Punjab (POB) & Centurion Bank & 2005 \\
\hline Bank of Baroda & South Gujarat Local Area Bank & 2004 \\
\hline Oriental Bank of Commerce & Global Trust Bank & 2004 \\
\hline Punjab National Bank & Nedungadi Bank Ltd. & 2003 \\
\hline ICICI Bank & ICICI Ltd. & 2002 \\
\hline Bank of Baroda & Benares State Bank Ltd. & 2002 \\
\hline ICICI Bank Ltd & Bank of Madura Ltd & 2001 \\
\hline HDFC Bank Ltd. & Times Bank Ltd. & 2000 \\
\hline Bank of Baroda & Bareilly Corporation Bank Ltd. & 1999 \\
\hline Union Bank of India & Sikkim Bank Ltd. & 1999 \\
\hline Oriental Bank of Commerce & Bari Doab Bank Ltd. & 1997 \\
\hline Oriental Bank of Commerce & Punjab Co-operative Bank Ltd. & 1996 \\
\hline State Bank of India & Kashinath State Bank Ltd & 1995 \\
\hline Bank of India & Bank of Karad Ltd. & 1994 \\
\hline Punjab National Bank & New Bank of India & 1993 \\
\hline Bank Of India & Parur Central Bank Ltd. & 1990 \\
\hline Central Bank Of India & Purbanchal Bank Ltd. & 1990 \\
\hline Indian Bank & Bank of Thanjavur Ltd. & 1990 \\
\hline Indian Overseas Bank & Bank of Tamilnadu Ltd & 1990 \\
\hline Allahabad Bank & United Industrial Bank Limited & 1989 \\
\hline Bank of Baroda & Traders Bank Ltd & 1988 \\
\hline Punjab National Bank & Hindustan Commercial Bank Ltd & 1986 \\
\hline State Bank of India & Bank of Cochin Ltd & 1985 \\
\hline Canara Bank & Lakshmi Commercial Bank Ltd & 1985 \\
\hline Union Bank of India & Miraj State Bank Ltd & 1985 \\
\hline State Bank of India & National Bank of Lahore Ltd & 1970 \\
\hline State Bank of India & Bank of Bihar Ltd & 1969 \\
\hline
\end{tabular}

Source: Reserve Bank of India

It was originated and started working as the Bank of Calcutta in mid-June 1806. In 1809, it was renamed as the Bank of Bengal. Later on, the presidential government merged three banks in 1921 to form the Imperial Bank of India, the Bank of Bengal and the other two were the Bank of Bombay and the Bank of Madras which were founded in 1840 and 1843. These three banks after 1947 India's independence were known as the State Bank of India in 1955. This phenomenon of mergers has not stopped even after nationalization of SBI. The events like merger and acquisition were not so much popular up to 1980's because there were a very small percentage of businesses running in the country. However mostly all the merger during that period were friendly acquisition with a negotiated deal. However, at the beginning of 1990's the volume was tremendously increased nearly four times more merger than before. The most recent mergers in the Indian banking are SBI merged with associate in 2017, Kotak Mahindra bank 
merged with ING Vyasa Bank in 2014 and ICICI Bank merged with Bank of Rajasthan in 2010. Table 3 shows the list of banks mergers and acquisition since nationalization of banks in India.

\section{The proposed study}

This paper examines the impact of Merger and Acquisition(M\&As) on volatility of SBI security return.

\subsection{Hypothesis of the Study}

$\boldsymbol{H}_{0}$ 1: The occurrence of M\&As does not impact the volatility of stock return of State Bank of India.

\subsection{Research Methodology}

The data used in this paper have been collected from some reliable sources. The historical daily security data of State Bank of India were retrieved from Bombay stock exchange which include daily stock price quotations of banks involved in Merger and Acquisitions. The research is limited to acquiring bank due to scarcity of data of acquired bank after M\&As. The analyzed series covers the period from 18/7/2016 to 29/9/2017 nearly 300 (event window) working days. The period of analysis is shorter, because the researcher wants to examine the volatility of stock returns with respect to the M\&As. Thus the stock price series of the acquiring bank was transformed into the return series. The market return of SBI security price is calculated using the formulae,

$R=\frac{P i-P j}{P j} \times 100$.

By defining a return: $\mathrm{r}_{\mathrm{i}}$ at time $\mathrm{i}$, where $\mathrm{p}_{\mathrm{i}}$ is the price at time $i$ and $j=(\mathrm{i}-\mathrm{j})$ : Firstly, Researchers have checked return series with the help of graph to know the outlier or break point. If it was observed that the behaviour is changing on certain point then the researchers have opted to go for Stationarity test. Stationarity literally mean riveting, again and again crossing their mean. Historically, the stationary of data is usually derived from time plot and Correlogram. The unit root test determines whether a time series is stationary or not, to deal this problem, the researchers applied Augmented Dickey-Fuller Test on return series and found data is stationary at level, where exogenous constant, Constant with linear trend and none are satisfied (See Table 4). The researchers chose lag length automatically by e-views software to run the test, the lag length should be selected rationally so that the residuals are not serially correlated.

Table 4

Exhibit the Output of Augmented Dickey-Fuller Test Statistic at Exogenous Constant, Constant with Linear Trend and None

\begin{tabular}{lccc}
\hline Exogenous (Regression model) & Test critical values at 5\% level & t-Statistic & Prob. ${ }^{*}$ \\
\hline Constant & & -17.79362 & 0.0000 \\
Constant, Linear Trend & -3.870996 & -17.87483 & 0.0000 \\
None & -1.941888 & -17.81519 & 0.0000 \\
\hline Source: Output E-views by rear
\end{tabular}

Source: Output E-views by researchers' compilations

\section{Results and Discussion}

After testing the Stationarity of the return series, the researchers have to check the residual diagnostic with three statistics Correlogram Q-statistics, Correlogram squared residual and Heteroscedasticity test, the researchers estimated the equation at $\mathrm{C}$, where researchers checked the condition of satisfied equation by residual diagnostics which includes the Correlogram Q-statistics, Correlogram squared residual and Heteroscedasticity tests. The unstable behaviour of the volatility or Heteroscedasticity of the stock of the SBI stock return of acquiring bank, an initials visual analysis of the graph indicates that the return of the stock show high volatility and shows the stylized facts in the financial time series (See Fig. 2), which indicates the use of Arch class statistical model which is an important tool to support decision making, evaluation and final result before estimating the mean and variance equation, in pre-test for estimating model. 


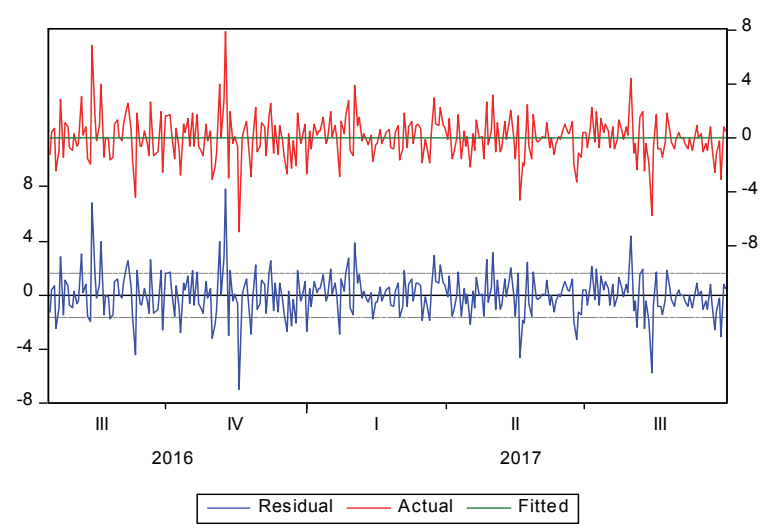

Source: Output E-views

Fig. 2. Actual, fitted and residuals of SBI security return of 300 days

The autocorrelation coefficient has revealed a predictable pattern of the conditional mean of the stock return of the acquiring bank. The same pattern was observed for the estimated autocorrelation for the squared return of the series. This gives some evidence of Arch effect in the variance of the return series of the banking stock. Residual diagnostic is to be tested for best fit model for estimating volatility of SBI stock return. Therefore, the researchers checked the residual diagnostic and tested the return series to Correlogram q-statistics, here the information of the announcement of the merger gives negative as well as positive reaction of the stock return. Both auto correlation and partial correlation values show negative or positive sign. All the p-value are shown more than 0.05 which show the model was viable or acceptable (See Table 5). Simultaneously, Correlogram square residual shows that mean return was based on the past term, where the p-value is greater than 0.05 which is satisfactory for model (See Table 6 ). Lastly the researchers examined the hetroscedasticity (Arch test) by taking six lags under the selected period of event window (300 days) which showed p-value is 0.0024 (See Table 7) and clearly stated that there was Arch effect, therefore, the researchers moved to variance equation. Finally after estimating the mean equation, the researchers have taken the residual for estimating the variances of the residual equation. The method used ML-Marquardt normal distribution, the convergence achieved after 18 iterations and the pre-sample variance or back cast parameter (0.7). Under 300 days observations, in the mean equation variable return SBI is regressed at constant, which shows the coefficient is 0.033729 and the standard error is 0.086181 . The Z-statistics is 0.391373 and p-value is equal to 0.6955 , the variance equation (C2) shows the p-value is 0.0017 , the resid $(-1)^{\wedge} 2$ is 0.0010 , which shows variance was dependent on squared residual. Garch (-1) shows the p-value of 0.000 which is highly significant, which means the volatility is associated with the previous day or variance is dependent on the past term or conditional variance and is affected by previous day variance (See Table 8).

$G A R C H=C(2)+C(3) \times R E S I D(-1)^{\wedge} 2+C(4) * G A R C H(-1)$

After estimating the model, the researchers examined the goodness of the fit. In order to find out whether the Arch-Garch $(1,1)$ model is viable or not, the researchers checked all the convention again in the post model formed.

1. Autocorrelation: after the estimation of the model, we have found that there was no serial correlation in the residual term, where the p-value lies greater than 0.05 shown in Table 9.

2. Arch effect; In the post estimation analysis, the result shows that F-statistics is 0.48 and p-value is equal to 0.488 which is more than 0.05 and this means the Hetroscedasticity has been removed, for the LM-test which has been performed (See Table 11).

3. All the values of Correlogram square residual are above 0.05 which is acceptable for the model (See Table 10). 


\section{Final comments}

This study has examined the impact of announcement of mergers on the volatility of banking stock return by using Arch-Garch model. The result shows that mergers were responsible for an increase in security return volatility on different ways, however it suggests that merger tend to have negative or positive reaction, but here the results have indicated some volatility in the stock and after the merger of SBI and associates increased SBI market shares from 17 to 23 percent in post-merger, which means that SBI benefited from the merger with their associate's banks. The study evaluated the impact of Merger and Acquisitions on the volatility of the return of Indian Banking stock using Garch class model. The results have shown that M\&As were responsible for an increase in stock volatility and in different ways. Thus, our results do not support our assumption and the formulated hypothesis was rejected, therefore, there is a significant impact of mergers and acquisitions on the volatility of SBI stock returns. They suggested that the results may also be useful for prediction of security returns in the Indian banking sector, if the researchers consider other factors effecting on the volatility of the return, the results could also bring some new facts. Finally, researchers concluded that, more robust financial model could be used, such as E-Garch, T-Garch and Multivariate Garch Model.

Table 5

Exhibit the Pre-Estimation Model Output of Residual Diagnostics Correlogram Q- Statistics

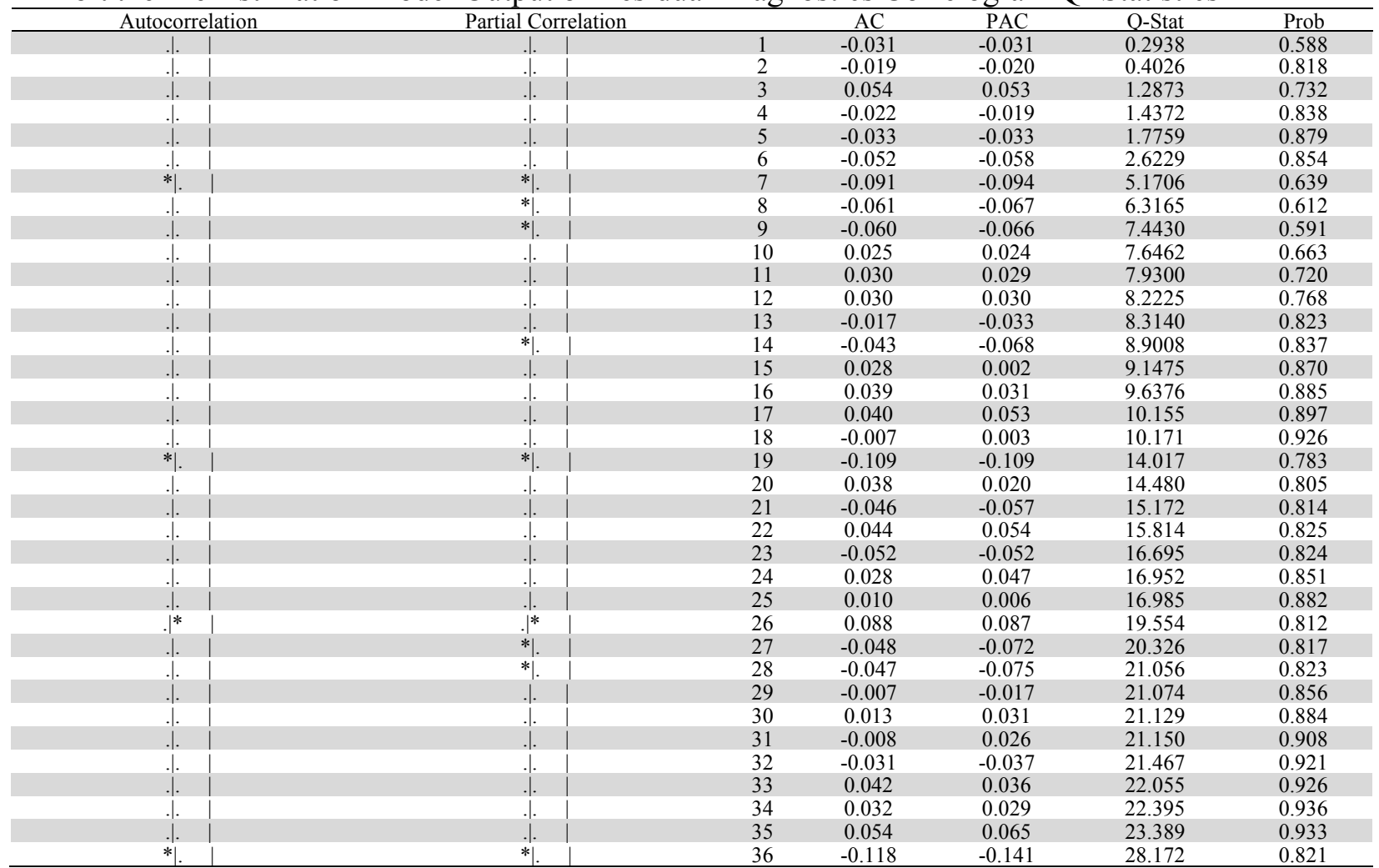

Source: Output by E-views

Table 6

Exhibit the Pre-Estimation Model Output of Residual Diagnostics Correlogram Squared Residuals Statistics

\begin{tabular}{|c|c|c|c|c|c|c|}
\hline Autocorrelation & Partial Correlation & & $\mathrm{AC}$ & PAC & Q-Stat & Prob \\
\hline .1. &.$|. \quad|$ & 1 & 0.049 & 0.049 & 0.7187 & 0.397 \\
\hline. &. & 2 & -0.028 & -0.030 & 0.9521 & 0.621 \\
\hline. &. & 3 & 0.070 & 0.073 & 2.4382 & 0.487 \\
\hline. $\mid$ &. & 4 & 0.027 & 0.019 & 2.6659 & 0.615 \\
\hline 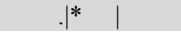 & . . $^{*}$ & 5 & 0.088 & 0.091 & 5.0644 & 0.408 \\
\hline.$* *$ &. & 6 & 0.233 & 0.225 & 21.841 & 0.001 \\
\hline. &. & 7 & -0.001 & -0.017 & 21.841 & 0.003 \\
\hline. &. & 8 & -0.064 & -0.063 & 23.120 & 0.003 \\
\hline. &. & 9 & 0.058 & 0.030 & 24.184 & 0.004 \\
\hline. $\mid$. & $*|. \quad|$ & 10 & -0.060 & -0.092 & 25.328 & 0.005 \\
\hline
\end{tabular}


Table 6

Exhibit the Pre-Estimation .... (Continued)

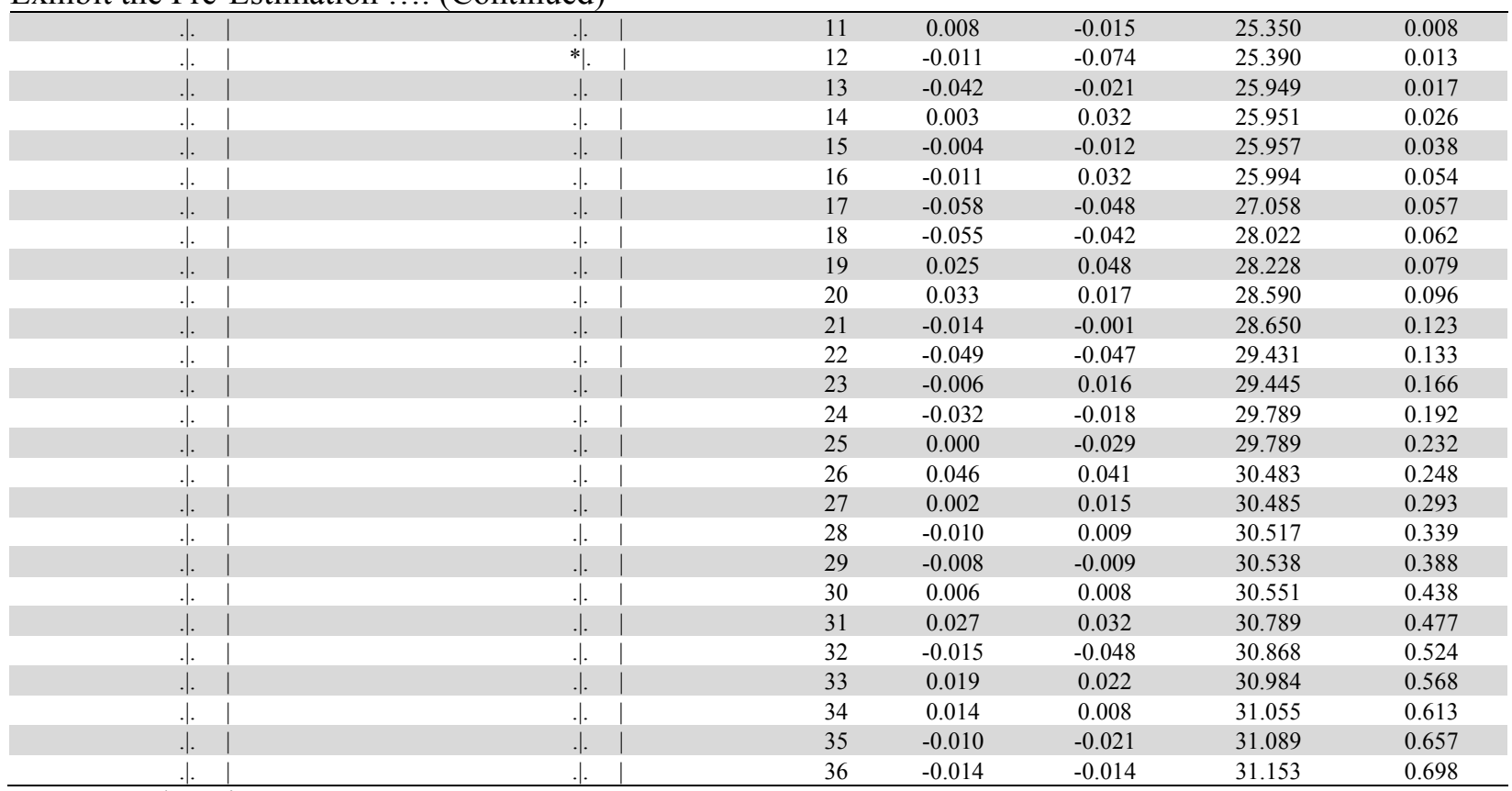

Source: Output by E-views

Table 7

Exhibit the Pre-Estimation Model Output of Residual Diagnostics by ARCH LM-Test Using Least Squares Method

\begin{tabular}{|c|c|c|c|c|}
\hline$\overline{\text { F-statistic }}$ & 3.483698 & Prob. F(6,287) & & 0.0024 \\
\hline Obs*R-squared & 19.95843 & Prob. Chi-Square(6) & & 0.0028 \\
\hline Variable & Coefficient & Std. Error & t-Statistic & Prob. \\
\hline $\mathrm{C}$ & 1.621489 & 0.490863 & 3.303344 & 0.0011 \\
\hline $\operatorname{RESID}^{\wedge} 2(-1)$ & 0.029697 & 0.057432 & 0.517070 & 0.6055 \\
\hline $\operatorname{RESID}^{\wedge} 2(-2)$ & -0.044760 & 0.057266 & -0.781624 & 0.4351 \\
\hline $\operatorname{RESID}^{\wedge} 2(-3)$ & 0.059944 & 0.057395 & 1.044414 & 0.2972 \\
\hline $\operatorname{RESID}^{\wedge} 2(-4)$ & 0.023760 & 0.057411 & 0.413857 & 0.6793 \\
\hline $\operatorname{RESID}^{\wedge} 2(-5)$ & 0.080453 & 0.057366 & 1.402435 & 0.1619 \\
\hline $\operatorname{RESID}^{\wedge} 2(-6)$ & 0.226011 & 0.057558 & 3.926696 & 0.0001 \\
\hline R-squared & 0.067886 & Mean dependent var & & 2.595085 \\
\hline Adjusted R-squared & 0.048399 & S.D. dependent var & & 6.262670 \\
\hline S.E. of regression & 6.109237 & Akaike info criterion & & 6.481002 \\
\hline Sum squared resid & 10711.64 & Schwarz criterion & & 6.568707 \\
\hline Log likelihood & -945.7073 & Hannan-Quinn criter. & & 6.516125 \\
\hline F-statistic & 3.483698 & Durbin-Watson stat & & 1.991134 \\
\hline Prob(F-statistic) & 0.002433 & & & \\
\hline
\end{tabular}

Source: Output by E-views

Table 8

Exhibit the ML - ARCH (Marquardt) - Normal distribution Model Output

\begin{tabular}{lrrrr}
\hline \multicolumn{1}{c}{ Variable } & Coefficient & Std. Error & Z-Statistic & Prob. \\
\hline \multicolumn{1}{c}{ C } & 0.033729 & 0.086181 & 0.391373 & \\
\hline \multicolumn{1}{c}{ C } & Variance Equation & & \\
\multicolumn{1}{c}{ RESID(-1)^2 } & 0.361860 & 0.115585 & 3.130683 \\
\multicolumn{1}{c}{ GARCH(-1) } & 0.142215 & 0.043107 & 3.299117 & 0.0017 \\
\hline R-squared & 0.730557 & 0.068884 & 10.60568 & 0.0010 \\
Adjusted R-squared & -0.000003 & Mean dependent var & 0.030721 \\
S.E. of regression & -0.000003 & S.D. dependent var & 1.614844 \\
Sum squared resid & 1.614847 & Akaike info criterion & 3.774999 \\
Log likelihood & 779.7110 & Schwarz criterion & 3.824383 \\
Durbin-Watson stat & -562.2499 & Hannan-Quinn criter. & 3.794763 \\
\hline Source: Out & 2.060045 & & & \\
\hline
\end{tabular}


Table 9

Exhibit the Post Estimation Model Output of Residual Diagnostics Correlogram Q- Statistics

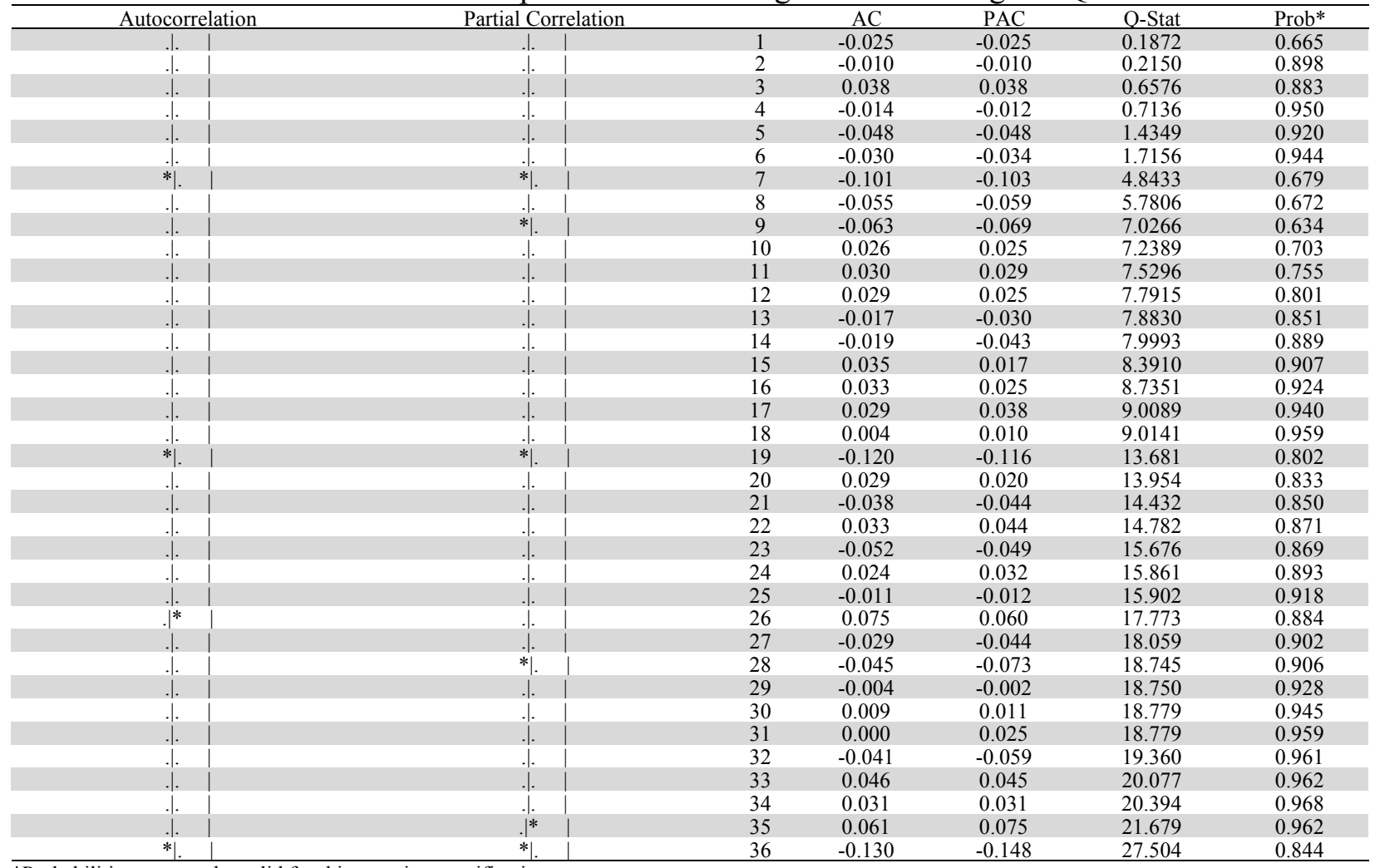

* Probabilities may not be valid for this equation specification.

Source: Output by E-views

\section{Table 10}

Exhibit the Post Estimation Model Output of Residual Diagnostics Correlogram Squared Residuals Statistics

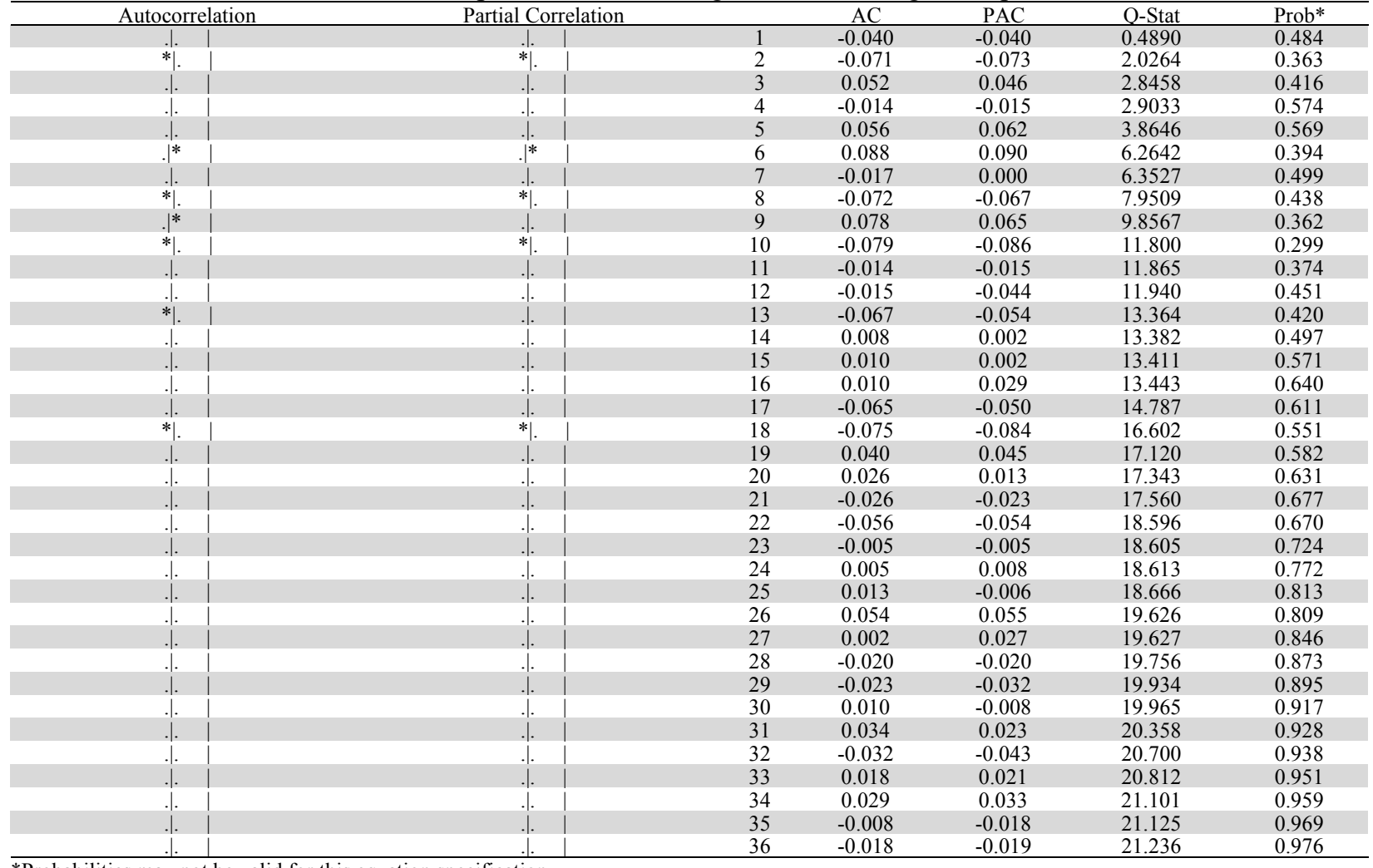


Table 11

Exhibit the Post Estimation Model Output of Residual Diagnostics by ARCH LM-Test Using Least Squares Method

\begin{tabular}{|c|c|c|c|c|}
\hline$\overline{\text { F-statistic }}$ & 0.480431 & Prob. $\mathrm{F}(1,297)$ & & 0.4888 \\
\hline Obs*R-squared & 0.482885 & Prob. Chi-Square(1) & & 0.4871 \\
\hline Variable & Coefficient & Std. Error & t-Statistic & Prob. \\
\hline $\mathrm{C}$ & 1.040632 & 0.132501 & 7.853787 & 0.0000 \\
\hline WGT RESID ${ }^{\wedge} 2(-1)$ & -0.040200 & 0.057997 & -0.693131 & 0.4888 \\
\hline$\overline{\mathrm{R} \text {-squared }}$ & 0.001615 & Mean dependent var & & 1.000325 \\
\hline Adjusted R-squared & -0.001747 & S.D. dependent var & & 2.056897 \\
\hline S.E. of regression & 2.058692 & Akaike info criterion & & 4.288686 \\
\hline Sum squared resid & 1258.750 & Schwarz criterion & & 4.313438 \\
\hline Log likelihood & -639.1585 & Hannan-Quinn criter. & & 4.298593 \\
\hline F-statistic & 0.480431 & Durbin-Watson stat & & 2.004742 \\
\hline Prob(F-statistic) & 0.488769 & & & \\
\hline
\end{tabular}

Source: Output by E-views

\section{References}

Alberg, D., Shalit, H., \& Yosef, R. (2008). Estimating stock market volatility using asymmetric GARCH models. Applied Financial Economics, 18(15), 1201-1208.

Anand, M., \& Singh, J. (2008). Impact of merger announcements on shareholders' wealth: Evidence from Indian private sector banks. Vikalpa, 33(1), 35-54.

Birau, R., Trivedi, J., \& Antonescu, M. (2015). Modeling S\&P Bombay Stock Exchange BANKEX Index Volatility Patterns Using GARCH Model. Procedia Economics and Finance, 32, 520-525.

Boon Tan, H., \& Wooi Hooy, C. (2004). Bank merger and bank stock volatility: a post-announcement analysis. Managerial Finance, 30(4), 29-47.

Cox, A. J., \& Portes, J. (1998). Mergers in regulated industries: The uses and abuses of event studies. Journal of Regulatory Economics, 14(3), 281-304.

Fama, E. F., \& Miller, M. H. (1972). The theory of finance. Holt Rinehart \& Winston.

Jayaraman, N., Mandelker, G., \& Shastri, K. (1991). Market anticipation of merger activities: An empirical test. Managerial and Decision Economics, 12(6), 439-448.

Karmakar, M. (2005). Modeling conditional volatility of the Indian stock markets. Vikalpa, 30(3), 2138.

Khan, A. A. (2011). Merger and Acquisitions (M\&As) in the Indian banking sector in post liberalization regime. International Journal of Contemporary Business Studies, 2(11), 31-45.

Khan, A. A., \& Ikram, S. (2012). Testing the efficiency of Indian stock market Vis-À-Vis merger and acquisitions-A Study of Indian Banking Sector. International Journal of Latest Trends in Finance and Economic Sciences, 2(2), 155-168.

Khan, A. A., \& Javed, S. (2017). A study of volatility behaviour of S\&P BSE BANKEX return in India: A pragmatic approach using GARCH model. International Journal of Advanced and Applied Sciences, 4(4), 127-132.

Pessanha, G. R. G., Bruhn, N. C. P., Calegario, C. L. L., Sáfadi, T., \& Ázara, L. N. D. (2016). Mergers and Acquisitions and Market Volatility of Brazilian Banking Stocks: An Application of GARCH Models. Latin American Business Review, 17(4), 333-357.

Seo, M., Lee, S., \& Kim, G. (2019). Forecasting the Volatility of Stock Market Index Using the Hybrid Models with Google Domestic Trends. Fluctuation and Noise Letters, $18(01), 1950006$.

Shanmugasundram, G., \& Benedict, D. J. (2013). Volatility of the Indian Sectoral Indices-A Study with reference to National Stock Exchange. International Journal of Marketing, Financial Services \& Management Research, 2(8), 1-11.

Zhu, P., Jog, V., \& Otchere, I. (2014). Idiosyncratic volatility and mergers and acquisitions in emerging markets. Emerging Markets Review, 19, 18-48.

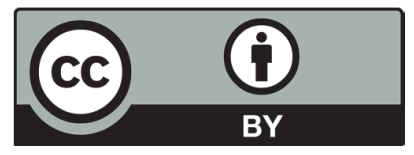

(C) 2019 by the authors; licensee Growing Science, Canada. This is an open access article distributed under the terms and conditions of the Creative Commons Attribution (CCBY) license (http://creativecommons.org/licenses/by/4.0/). 